\title{
Saving Ghana's Revolution: The Demise of Kwame Nkrumah and the Evolution of Soviet Policy in Africa, 1966-1972
}

\author{
Natalia Telepneva
}

\begin{abstract}
On 24 February 1966, Ghana's first president, Kwame Nkrumah, was overthrown in a coup d'etat. The coup rekindled a debate at various levels of the Warsaw Pact about the prospects of socialism in Africa and about which policies were desired. Soviet officials concluded they would have to pay more attention to establishing relationships with the military and security apparatus of African countries. This paper explores how Nkrumah's loyalists in exile and their sympathizers in Ghana attempted to launch a counter-coup in 1968 and the role of the Warsaw Pact countries-notably the Soviet Union and Czechoslovakia-in those events. It provides an insight into "Operation ALEX"-a botched attempt by the Czechoslovakian intelligence service to support Nkrumah loyalists in their attempts to launch a left-wing counter-coup in Ghana. This paper re-examines the late 1960s as an important period of militarization of the Cold War in Africa and highlights the importance of local African agency in this process.
\end{abstract}

\section{Introduction}

On 24 February 1966, the first President of Ghana, Kwame Nkrumah, had only just landed in Beijing when he was informed of the coup d'état that had taken place earlier that morning in Ghana's capital, Accra. Nkrumah, who was on his way to a peace mission in North Vietnam, learned he had been dismissed as president of Ghana, and that his Convention People's Party (CPP) had been banned and replaced by a group calling themselves the National Liberation Council (NLC). Upon the invitation of Guinea's President Sékou Touré, Nkrumah would spend the rest of his life at Villa Silly in Guinea's capital, Conakry. He would never return to Ghana. Nkrumah's overthrow was in many ways a key moment in Africa's post-colonial history. Nkrumah was the embodiment of Pan-Africanism, and his fall signified an end to African unity as an ambitious political project. The coup also ended Accra's status as a locus for the postcolonial production of knowledge about Africa, centered on the Institute of African Studies, and a logistical hub for anti-colonial movements, which received financial assistance and training in Ghana. ${ }^{1}$

By 1966, the Soviet Union and other countries in the Warsaw Bloc engaged with Nkrumah's Ghana politically, economically, and militarily. A radical thinker, Nkrumah believed that African socio-cultural circumstances lent themselves more readily to socialism than to capitalism, a doctrine that came to be referred to as "African socialism." The Soviets initially saw Ghana as a showcase for the "socialist model of development," thus they provided development assistance and attempted to break the British monopoly on the

\footnotetext{
${ }^{1}$ Jean Allman, "Kwame Nkrumah, African Studies, and the Politics of Knowledge Production in the Black Star of Africa," The International Journal of African Historical Studies, Vol. 46, No. 2 (2013); and Jeffrey S. Ahlman, "Road to Ghana: Nkrumah, Southern Africa and the Eclipse of a Decolonizing Africa," Kronos, No. 37 (November 2011), pp. 23-40.
} 
country's cocoa trade. The Soviet and Ghanaian leadership cooperated during the Congo Crisis, and in 1961, Moscow agreed to Nkrumah's request for help in establishing a single African army. ${ }^{2}$ While substantial disagreements between the two countries had emerged by 1966, Moscow had a stake in Ghana. Nkrumah became increasingly anti-American towards the end of his rule, frustrated by the US role in the Congo and convinced the CIA was plotting to assassinate him, with these convictions supported by forgeries prepared by the $\mathrm{KGB}^{3}$ In 1965, he authored a book Neo-Colonialism: The Last Stage of Imperialism, in which he accused the CIA of fomenting instability and crisis around the world. ${ }^{4}$

Nkrumah's fall was thus considerably a setback for Moscow, rekindling a debate within the Warsaw Pact surrounding the prospects for revolution in Africa. The coup initiated a series of unsuccessful attempts on behalf of the Soviet and Czechoslovak intelligence services to restore Nkrumah to power. This paper analyzes the attempts of the Czechoslovak rezidentura in Accra to assist members of Ghana's internal opposition to launch a countercoup, codenamed operation ALEX. The original goal of restoring Nkrumah to power would never be reached, and the Czechoslovak rezidentura in Accra eventually closed down in 1971. The KGB, however, continued attempts to undermine the Western security services in Ghana, with some success. This paper shows that the Soviets and their Czechoslovak allies did not lose their interest or hope in a socialist transformation in Africa following Nkrumah's downfall. This paper also emphasizes the importance of African agency in both the successes and failures of superpower rivalry in Ghana, thus contributing to our understanding of the Cold War in Africa. The key practical lesson the Soviets took from these setbacks was their underestimation of the importance of the army in Africa. Moscow would try to compensate by providing increasing amounts of training and equipment for the military and security service personnel of friendly regimes in Africa.

While the coup was in many ways a significant event, even beyond Africa, few historians have examined its significance or consequences in any detailed or sustained way. In his 1970 work on Soviet policy in West Africa, Robert Legvold argued that while anticipation of progress towards socialism in such countries as Ghana, Guinea, and Mali initially encouraged a sizeable Soviet economic offensive in these countries, by 1968 the Soviet Union had long been disabused of its revolutionary vision of Africa. Legvold sees Nkrumah's fall as a rupture, after which Soviet expectations of major revolutionary transformations in the region collapsed, diminishing the area's importance to the Soviets. ${ }^{5}$ Soviet policy in West Africa was not the subject of any major historical research for the following three decades, perhaps because the region was considered a backwater of the Cold War. However, interest in Cold War West Africa has been revived following the partial opening of Russian and Eastern European archives. Recent works by Sergey Mazov and

\footnotetext{
2 “Iz Dnevnika Marshala I.V. Kulikova," 1 July 2001, Kommersant, online at http://www.kommersant.ru/doc/2288946 (accessed 20 June 2016).

${ }^{3}$ Christopher Andrew and Vasili Mitrokhin, The KGB and the World: The Mitrokhin Archive II (London: Penguin Books, 2006), pp. 434-435.

${ }^{4}$ Kwame Nkrumah, Neo-Colonialism, The Last Stage of Imperialism (London: Thomas Nelson \& Sons, 1965), p. 251.

${ }^{5}$ Robert Legvold, Soviet Policy in West Africa (Cambridge, MA: Harvard University Press, 1970), pp. 335-344.
} 
Alessandro Iandolo show that West Africa was a scene of intense, if often unequal, competition between socialism and capitalism in the late 1950 s and the early 1960 s. $^{6} \mathrm{~A}$ number of authors have tackled the policies of what had previously been considered as Moscow's junior allies, such as Cuba and the socialist countries in Eastern Europe, arguing that these actors were not simply subservient to Moscow, but often followed an independent course in relations with African actors in pursuit of their own interests and principles. ${ }^{7}$

These works go a long way to explain the evolution of Soviet policy in Africa under Nikita Khrushchev, but few authors have addressed in any detail the evolution of the USSR's Africa policy in the late 1960s, the half-decade that predated renewed Soviet interventionism in Angola, Mozambique, Zimbabwe, and the Horn of Africa in the 1970s. Sandwiched between the better-known histories of Nikita Khrushchev's early policies towards West Africa in the late 1950s and the early 1960s and the intensification of Soviet involvement in Africa in the mid-1970s, the late 1960s deserve more attention as a moment of profound transition in Moscow's policy. In this period, Moscow launched a new, more military-heavy phase of engagement with Africa. This is all the more intriguing considering that the late 1960s has traditionally been considered a period when neither superpower deemed the region particularly important. This paper argues that this period was a crucial time in the development of the Cold War in Africa by looking at the ill-fated attempts between 1966 and 1968 of the Soviet and the Czechoslovakian intelligence services to sponsor a left-wing coup in Ghana.

This article draws upon recently declassified documents in Russia and Eastern Europe. Since the mid-1990s, Eastern European archives provided the only source of information about high-level Soviet policy in Africa as the records of decision-making bodies such as the Presidium of the Central Committee of the Communist Party of the Soviet Union (CC CPSU) and the CC CPSU International Department were still classified. However, Russian authorities have recently declassified a unique set of high-level documents, including reports sent to the International Department from diplomats and intelligence officers on the ground, and country overviews authored by senior figures in the Soviet Committee on State Security (KGB) and the Main Intelligence Directorate of the Soviet General Staff (GRU) the political and the military branches of Soviet secret intelligence. This article reveals how the GRU's chief, Petr Ivanovich Ivashutin, analyzed the situation in Ghana in the aftermath of the coup. The archival record is by no means complete, since it does not contain any details of GRU or KGB clandestine operations in Africa, naturally the most sensitive information. Nevertheless, Eastern European archives partially fill the gap. In particular, the records of the Czechoslovak intelligence reconstruct the details of Prague's involvement in Ghana and of operation ALEX. The full story remains buried in the Russian archives, but the

\footnotetext{
${ }^{6}$ Sergey Mazov, A Distant Front in the Cold War: the USSR in West Africa and the Congo, 1956-1964, Cold War International History Project Series (Stanford: Stanford University Press, 2010); and Alessandro Iandolo, "The Rise and Fall of the 'Soviet Model of Development' in West Africa, 1957-64," Cold War History, Vol. 12, No. 4 (November 2012), pp. 683-704.

${ }^{7}$ Pierro Gleijeses, Conflicting Missions: Havana, Washington, and Africa, 1959-1976 (Chapel Hill: University of North Carolina Press, 2002), pp. 373-396; Klaus Storkmann, Geheime Solidarität: Militärbeziehungen und Militärhilfen der DDR in die 'Dritte Welt' (Berlin: Ch. Links, 2012), pp. 6-33; and Philip Muehlenbeck, Czechoslovakia in Africa, 1945-1968 (Baringstoke, UK: Palgrave Macmillan, 2015), pp. 1-17.
} 
newly available documents give us a glimpse of the most secret part of the Cold War in Africa.

\section{Weapons for Nkrumah}

Nkrumah's downfall resulted in a 180-degree realignment of Ghana's foreign relations. By 1 March, the NLC had expelled at least 130 Soviet technicians and banned Aeroflot flights to Ghana. On 2 March, speaking on the radio, the NLC's Chairman, Major General Joseph Arthur Ankrah, announced the new economic guidelines for his regime: state corporations were to be re-examined and some returned to the private sector; the private sector would remain the largest in terms of persons employed and gross output; the government would resume negotiations with the IMF, World Bank, and associated institutions to obtain urgent financial aid; the new budget would emphasize reduced expenditure as opposed to increased taxation; and Nkrumah's prestige projects and the Seven Year Development Plan were to be abandoned. ${ }^{8}$ Within a week of the coup d'etat, the new regime ousted 620 Soviet technicians, teachers and advisers, working in schools, state farms, research institutes and government ministries. ${ }^{9}$ On 24 March, General Ankrah wrote a personal message to President Lyndon Johnson, in which he explained the decision to launch a coup in terms of an imminent communist threat and vowed to "remove all traces of alien ideological influence" from Ghana and improve relations with the West. He also asked for aid, food, and a credit line with the US to avoid economic disaster. ${ }^{10}$

The NLC's policies immediately raised questions about Western complicity in the coup. Nkrumah believed the coup was a product of collusion between the US and opposition forces within the Ghanaian army and police force, as he explained in his 1968 book, Dark Days in Ghana. ${ }^{11}$ Washington had good reasons to wish for Nkrumah's downfall. US officials were deeply concerned about Nkrumah's growing anti-Americanism and would regularly castigate the President for his inflammatory speeches against US actions abroad. ${ }^{12}$ On 27 May 1965, Deputy Special Assistant to the President for National Security Affairs, Robert Komer, wrote to President Lyndon Johnson's National Security Adviser, McGeorge Bundy: "The plotters are keeping us briefed, and State thinks we're more on the inside than the British. While we're not directly involved (I'm told), we and other Western countries (including France) have been helping to set up the situation by ignoring Nkrumah's pleas for economic aid." 13 While the specific role of the CIA's station chief in Accra, Howard T. Bane,

\footnotetext{
8 "News in Brief," Africa Report, Vol. 11, No. 4 (1966), p. 36.

${ }^{9}$ Legvold, Soviet Policy in West Africa, p. 263.

${ }^{10}$ Letter from Chairman of the National Liberation Council Lieutenant General Ankrah to President Johnson,1 Accra, 24 March 1966 in U.S. Department of State, Foreign Relations of the United States (FRUS), 1964-1968Africa, Vol. XXIV, Document 261, online at https://history.state.gov/historicaldocuments/frus196468v24/d261 (accessed 9 September 2016)

${ }^{11}$ Kwame Nkrumah, Dark Days in Ghana (London: Lawrence \& Wishart, 1968), pp. 49-51.

12 "Telegram From the Embassy in Ghana to the Department of State," Accra, 2 April, 1965, 6 p.m., in FRUS, 1964-1968, Vol. XXIV, Document 252, online at https://history.state.gov/historicaldocuments/frus196468v24/d252 (accessed 9 September 2016)

13 "Memorandum From Robert W. Komer of the National Security Council Staff to the President's Special Assistant for National Security Affairs (Bundy)" in FRUS, 1964-1968, Vol. XXIV, Document 253, online at https://history.state.gov/historicaldocuments/frus1964-68v24/d253 (accessed 9 September 2016)
} 
still remains unclear, US officials knew about the plot and facilitated it by denying Nkrumah's requests for economic assistance. On 20 November 1965, the US officially turned down Ghana's long-pending request for over $\$ 100$ million in food assistance, not least due to the release of Nkrumah's book Neo-Colonialism: The Last Stage of Imperialism, proof of what the US State Department believed was "Nkrumah's fundamental anti-Western, anti-US bias." 14

US officials were predictably happy with the outcome of the coup and eager to support the NLC. On 12 March, Robert Komer, writing to President Johnson, described the coup in Ghana as a "fortuitous windfall": Nkrumah had been doing more to undermine US interests than any other black African, while the new military regime was almost pathetically pro-Western. ${ }^{15}$ On 14 April, President Johnson praised Ankrah's alertness to the "dangers of subversion from alien sources" and praised attempts to reinstate the rule of law and overcome economic difficulties. ${ }^{16}$ The honeymoon period between the US and post-Nkrumah Ghana included a mutually beneficial exchange: the US airlifted food aid, while Ankrah shared antiaircraft guns and ammunition of the type being used against the Americans in Vietnam. ${ }^{17}$

Much of early Soviet optimism about the possibilities of a socialist revolution in Africa had been crushed by 1966. In the late 1950s, CC CPSU First Secretary Nikita Khrushchev believed that assistance to the newly decolonized nations offered a new frontier for socialism and that it was the USSR's duty to provide assistance and thus display how Soviet socialism could compete peacefully with Western capitalism. ${ }^{18}$ These hopes quickly turned to disillusionment, as Guinea, Mali, and Ghana failed to turn into successful cases for the "socialist model of development." 19 The Soviets became frustrated that African leaders were eager to receive assistance from Moscow, but did not feel compelled to give back much in return, as when Guinea's Sékou Touré denied Moscow the use of Guinea's airfields during the Cuban Missile Crisis in $1962 .{ }^{20}$ This negative sentiment was reflected in a report drafted

\footnotetext{
14 "Circular Telegram From the Department of State to Embassies in Africa," Washington, 23 November, 1965, 7:26 p.m., in FRUS, 1964-1968-Africa, Vol. XXIV, Document 256, online at https://history.state.gov/historicaldocuments/frus1964-68v24/d256 (accessed 9 September 2016) 15 "Memorandum From the President's Acting Special Assistant for National Security Affairs (Komer) to President Johnson," Washington, 12 March, 1966, in FRUS, 1964-1968-Africa, Vol. XXIV, Document 260, online at https://history.state.gov/historicaldocuments/frus1964-68v24/d260 (accessed 9 September 2016) 16 "Letter From President Johnson to Chairman of the National Liberation Council Lieutenant General Ankrah," Washington, 14 April 1966, in FRUS, 1964-1968-Africa, Vol. XXIV, Document 262, online at https://history.state.gov/historicaldocuments/frus1964-68v24/d262 (accessed 9 September 2016) 17 "Memorandum From the President's Special Assistant (Rostow) to President Johnson," Washington, 8 July 1966, 7:15 p.m., in FRUS, 1964-1968-Africa, Vol. XXIV, Document 263, online at https://history.state.gov/historicaldocuments/frus1964-68v24/d263 (accessed 9 September 2016). Also see David Rooney, Kwame Nkrumah: Vision and Tragedy, (Accra: Sub-Saharan Publishers, 2007), p. 34 ${ }^{18}$ See Sergey Khrushchev, Nikita Khrushchev: Creation of a Superpower (University Park: Pennsylvania State University Press, 2000), p. 436; and Georgiy Mirskiy, "Na Znamenatel'nom Rubezhe," Vostok, Vol. 6 (1996), p. 131.

${ }^{19}$ Alessandro Iandolo, "The Rise and fall of the 'Soviet Model of Development' in West Africa, 1957-64," Cold War History, Vol. 12, No. 4 (November 2012), pp. 683-704.

${ }^{20}$ For a detailed discussion, see Mazov, "A Distant Front."
} 
by the KGB for the October 1964 Plenum of the CC CPSU as evidence of Khrushchev's mismanagement of foreign policy. ${ }^{21}$

Khrushchev's departure in October 1964 didn't signal an end to Moscow's interest in Africa. There was continuity because the key figures in Soviet policy in Africa, such as the head of the CC CPSU International Department, Boris Ponomarev; the head of the Africa section, Petr Manchkha; and other middle-ranking functionaries retained their posts. In fact, shortly after Khrushchev's ouster in October, the CC CPSU approved the construction of a special center for the training of foreign militants at the village of Perevalnoye, Soviet Ukraine, and stepped up deliveries of weapons to the liberation movements in the Portuguese colonies. $^{22}$ On 19 June 1965, Soviet policy in Africa suffered yet another blow when Hourari Boumédiène overthrew the first president of Algeria, Ahmed Ben Bella. Moscow was gravely concerned about the loss of a key ally in the region, but soon realized the coup did not represent a drastic realignment of Algeria's foreign policy. ${ }^{23}$ A Soviet diplomat, Leonid Musatov, who witnessed the 1968 coup in Mali reflected that Moscow felt that the episode could not compare to events in Ghana because the demise of Nkrumah's regime had been "very painful" for the Soviet leadership. ${ }^{24}$ A veteran of the Second World War, Leonid Brezhnev believed in the concept of proletarian internationalism and was familiar with Nkrumah. In February 1961, Brezhnev held a series of conversations with Nkrumah in Accra about the crisis in the Congo and recommended that the Soviet Union consider supplying the opposition with light weapons and ammunition via Ghana and Morocco. ${ }^{25}$

Nkrumah's downfall therefore rekindled discussions about Soviet policy in Africa at various levels of the Soviet bureaucracy. One lesson from the coup was that the Soviets had misjudged the importance of the army, as the deputy foreign minister Yakov Malik told a Czechoslovakian delegation in April 1966. From then on, argued Malik, the foreign ministries of the socialist countries would have to make sure that their staff treated military and police forces as powerful political players in their own right, with ambassadors already delivering the necessary reports on the issue. ${ }^{26}$ The KGB held a similar view. In a conversation with the Bulgarian delegation visiting Moscow shortly after the coup, KGB Chairman Vladimir Semichastnyi said that they had underestimated the importance of intelligence work: "Africa should become a serious object of our attention." ${ }^{27}$ The most

\footnotetext{
21 "Doklad Prezidiuma TsK KPSS na Oktyabr'skom Plenume TsK KPSS (Variant)," n.d., online at http://onisland.net/History/1964.htm (accessed 2 September 2016).

22 Natalia Telepneva, "Our Sacred Duty: The Soviet Union, the Liberation Movements in the Portuguese Colonies, and the Cold War, 1961-1975," Ph.D. Diss., London School of Economics, 2015, pp. 103-140.

23 "Notatka dotyczy: aktualnej sytuacji w Algierii, na podstawie rozmowy z tow. Rumiancewem, Kierownikiem Sekcji Arabskiej Wydziali Mirdzynarodowego KC KPZR," Antoni Kuzba (Polish First Secretary, Moscow) to Warsaw, 28 July 1965, AMSZ, 58.70.W1, pp. 2-6.

${ }^{24}$ Leonid Musatov, "Afrikanskie Marshruty," in Vasilyev, ed., Afrika v Vospominaniiakh Veteranov Diplomaticheskoi Sluzhby (Moscow: Institut Afriki RAN, 2000), p. 12.

${ }^{25}$ Sergey Mazov, Kholodnaya Voyna v 'Serdze Afriki'. SSSR i Kongolezskiy Krizis, 1960-1964 (Moskva: Russkiy Fond Sodeystviya Obrazovaniyu i Nauke, 2015), p. 135.

${ }^{26}$ Vaclav David (CSSR Foreign Minister) to Antonin Novotny (CSSR General Secretary), Prague, 7 May 1966 , Národní Archiv, KSČ-ÚV-ANII, F. 1261/0/44, Inv. Č. 2, Ka. 3.

${ }^{27}$ Information given to Angel Solakov on the visit of a Bulgarian CSS delegation to the Soviet Union and their meetings with the leadership of the KGB First Chief Directorate, March 18, 1966, in Tatyana Kiryakova, ed., The KGB and the Bulgarian State Security Service - Connections and Dependences (Sofia: The Committee for
} 
comprehensive reviews of the situation in Ghana available come from the GRU chief, General Petr Ivashutin.

By 1966, Ivashutin had already very significant intelligence experience. Born the son of a railway worker in the town of Brest, modern-day Belarus, in 1909, Ivashutin worked on the railways and in a factory before completing training as a military pilot in 1933 before serving in military counter-intelligence from 1939. He rose to the rank of Lieutenant General at the end of the Second World War and was promoted to the post of KGB deputy chairman in 1954; he worked there until 1963, when he replaced Ivan Serov following the arrest and execution of CIA informant, GRU colonel Oleg Penkovsky. ${ }^{28}$ An agency within the Soviet Ministry of Defense, the GRU was responsible for training foreign militants, running arms to the liberation movements and collecting and analyzing information about the situation across the world with the help of local confidential contacts.

In a lengthy explanation of the situation in Guinea, Congo-Brazzaville and Somalia for the International Department on 6 August 1966, Ivashutin argued the coup in Ghana would encourage Western powers to intensify their subversion of African countries friendly to the USSR. The main goal, according to Ivashutin, was to turn them away from noncapitalist development and force them to reject close cooperation with the Soviet Union. The USA, UK, France, and the Federal Republic of Germany used members of the pro-Western African Unions - the African and Malagasy Union and the Conseil de l'Entente (Council of Understanding) — to destabilize regimes in Mali, Guinea, and Congo-Brazzaville by means of creating subversive groups and propaganda. ${ }^{29}$ In a similar analysis two months later, Ivashutin argued that the rise of African nationalism, faced with Western powers' intensifying struggle to maintain their influence, made Africa one of the most dangerous regions in the world, with Guinea, Nigeria, and Congo-Brazzaville likely to see armed antigovernment uprisings and coups. As for Ghana, Ivashutin did not believe that any organized opposition to the military regime existed but did not exclude the possibility that growing disappointment with economic difficulties would in the future lead to the "unification of progressive elements inside the country." The NLC had recently intensified propaganda against socialist countries, which showed, according to Ivashutin, that the junta feared an uprising of Nkrumah's supporters. ${ }^{30}$

The NLC were indeed moderately concerned about the threat emanating from Guinea. When Nkrumah arrived in Conakry on 2 March as a guest of Guinea's President Sékou Touré, he made it apparent that he intended to resume his role as the democratically elected president: "I want to say here that I am retuning to Ghana. I am en route for Ghana." ${ }^{31}$ On 10 March, Sékou Touré made a three-hour speech declaring that he was able to send troops to

Disclosing the Documents and Announcing Affiliation of Bulgarian Citizens to the State Security and the Intelligence Services of the Bulgarian National Army, 2009), p. 130.

${ }^{28}$ Alexandr Kolpakidi and Mikhail Seryakov, Shit i Mech.Rukovoditeli Organoz Gos. Bezopasnosti:

Rukovoditeli Organov Bezopasnosti Moskovskoi Rusi, Rossiiskoi Imperii, Sovetskogo Soyuza i Rossiiskoi

Federazii: Enziklopedicheskiy Spravochnik (Moscow: Olma-Press, 2002), p. 504.

${ }^{29}$ Petr Ivashutin to CC CPSU (International Department), 6 August 1966, in Rossiiskii Gosudarstvennyi Arkhiv Noveishei Istorii (RGANI), FOND (F.) 5, OPIS (Op.) 58, DELO (D.) 302, pp. 162-170.

${ }^{30}$ Petr Ivashutin to CC CPSU (International Department), 20 October 1966, RGANI, F. 58, D. 302, pp. 289-300

31 "News in Brief," Africa Report, Vol. 11, No. 4, p. 37. 
liberate the people of Ghana. ${ }^{32}$ On 14 March, General Ankrah summoned the Canadian, Australian and British High Commissioners to discuss the threat from Guinea, asking for assurances of support. ${ }^{33}$ The British did not believe Touré's threats were realistic. From a series of reports from their diplomatic stations in the region, Whitehall learnt that any regional initiative to help Nkrumah was seriously lacking. Not only would Mali's support for Touré's scheme endanger the country's exports to the Ivory Coast, but it also would have put an end to Franco-Malian talks on Mali's re-entry into the franc zone. Moreover, Guinea lacked the means to send sufficient forces to Ghana. The British Joint Intelligence Committee thus concluded that Touré's threats were not to be taken seriously because it was "extremely improbable" that any African countries which sympathized with Nkrumah would get involved in the adventure. ${ }^{34}$

While the British report does not mention the possibility of Soviet assistance as a concern, the Soviet leadership was initially prepared to support Nkrumah's ambitions. The Soviet Ambassador to Ghana, Aleksey Voronin, recalls that Sékou Touré invited him for a private meeting, asking Moscow for urgent military aid to facilitate Nkrumah's return to Accra. It is not clear what kind of aid was actually requested, but it was enough to put off the Soviet Ambassador: "I expressed my concerns, but relayed his request to the Foreign Ministry." 35 He was thus shocked to receive a telegram from Moscow informing him that Touré's request for aid had been considered and that a military ship would shortly arrive in Conakry, loaded with weapons and ammunition. The mission of the naval ship was unclear; it might have been supposed to unload weapons in Conakry for Nkrumah's supporters or to continue to Accra. Voronin believed the decision was adventurist and wrote a letter to the CPSU, advising against dispatching the ship: "The reality was such that even if the ship had arrived in Conakry, it would not have reached Accra without conflict. It would have had to clash with the military forces of the junta that had taken power in Ghana." The Soviet Ambassador would later discover that the CC CPSU Politburo engaged in a vigorous debate over whether or not to send the ship to Conakry, with General Secretary Leonid Brezhnev arguing in favor of dispatching the ship, opposing the view of the Chairman of the Council of Ministers, Aleksey Kosygin. ${ }^{36}$

Voronin's arguments seem to have tipped the balance in Kosygin's favor. Moscow agreed to his recommendation and recalled the ship, which was apparently on its way to Conakry. Shortly afterwards, General Viktor Kulikov, who had previously served as the Soviet military adviser to Ghana, arrived to explain the decision to Touré and Nkrumah. Voronin remembered that he and General Kulikov explained that it was impossible to use Soviet armed forces against the NLL, and eventually Nkrumah and then Touré agreed. ${ }^{37} \mathrm{We}$ still do not know when this aborted mission took place, but on 12 April, Nkrumah gave his

\footnotetext{
${ }^{32}$ From Dakar to Foreign Office, 11 March 1955, National Archives, DO195/219, p. 9

33 “"Threat From Ghana," Miles to Foreign Office, Telegram No. 375, 17 March 1966, National Archives, DO $153 / 39$, p. 10

${ }^{34}$ Joint Intelligence Committee, "Review of Current Intelligence as at 15th March, 1966," National Archives, DO 195/219.

${ }^{35}$ Aleksey Voronin, "Korabl Vozvratilsya v Port," Diplomaticheskiy Vestnik, No. 7-12 (1995), p. 79.

${ }^{36}$ Ibid.

${ }^{37}$ Ibid. Victor Kulikov would serve as the Chief of General Staff between 1971 and 1977.
} 
only press interview to Douglas Rogers for Africa and the World, in which he rejected any prospect of a Guinean invasion of Ghana. ${ }^{38}$

This episode shows that the Soviet practical response to Nkrumah's downfall was more dramatic than previously thought. While the possibility of a military action against the NLC seemed ludicrous, not only to the British diplomats, but also to Soviet Ambassador Aleksey Voronin, the CC CPSU seems to have entertained the possibility of such action, spurred by Touré's and Nkrumah's requests for support. While we still do not know the details of the plan with the ship or when it was undertaken, Voronin seemed fairly shocked, enough so to write a rebuttal. In the end, the Soviet officials seem to have been reminded that their abilities to project military power in Africa were limited and that the initiative for Nkrumah's restoration would have to come "from below." However, this did not mean that Soviet intelligence and its Czechoslovakian counterpart gave up attempts to restore Nkrumah to power by clandestine means.

\section{Agent LUPA}

Nkrumah's public rejection of military intervention did not stop a stream of reports of clandestine subversion. The NLC claimed that both Russia and China were supplying Guinea with arms and instructors to enable Nkrumah and his group of supporters to carry out guerrilla raids on Ghanaian soil. Nkrumah was also reported to have been promised a shipload of arms from the Chinese government when he was in Beijing, at the time of his overthrow. There were also reports that Russian arms, including T-34 tanks and armored cars, had been sent across the desert from Algeria to Mali and conveyed to a secret camp used by Nkrumah's followers as their military training ground, near Guinea's border with the Ivory Coast. ${ }^{39}$ The NLC leadership thus remained on high alert. When the British High Commissioner to Ghana, Harold Smedley, met General Emmanuel Kwasi Kotoka on 28 September, he expressed concern about Nkrumah's supporters surfacing once more and threatening NLC supporters with retaliation upon restoration of the former regime. ${ }^{40}$

Nkrumah never gave up the prospect of returning to Ghana. June Milne, his friend and long-time assistant, writes that only weeks after settling at Villa Silly in Conakry, Nkrumah started to receive a flow of messages from many people claiming to be organizing a counter-coup in Accra to restore him to power. Milne, who maintained a regular correspondence with Nkrumah, writes that he was told several times of an actual coup. On at least one occasion he was persuaded to spend the night at Sékou Touré's residence so that he would be ready to broadcast an address and make a quick return to Accra. ${ }^{41}$ On 17 April 1967, a group of disgruntled military officers launched an unsuccessful coup attempt in Accra, raising questions regarding political instability and disillusionment in the army. ${ }^{42}$

\footnotetext{
${ }^{38}$ June Milne, Kwame Nkrumah: The Conakry Years, His Life and Letters (London: Atlantic Highlands, 2009), p. 13.

39 "More Arms for Nkrumah," The Economist, July 21 1966, The National Archives, DO 195/219, p. 91.

${ }^{40}$ H. Smedley to London, 29 September 1966, The National Archives, DO 195/218, p.103.

${ }^{41}$ Milne, Kwame Nkrumah, p. 11.

42 "Special Memorandum Prepared in the Central Intelligence Agency," Washington, 19 July 1967, in FRUS, 1964-1968-Africa, Vol. XXIV, Document 268, online at https://history.state.gov/historicaldocuments/frus1964-68v24/d268 (accessed 9 September 2016)
} 
Meanwhile, GRU chief Petr Ivashutin believed that Nkrumah's chances were fairly slim. In a lengthy evaluation of the situation in Ghana and Guinea from 19 April 1967, Ivashutin outlined the situation in the country as characterized by increasing division between the faction headed by General Ankrah, who favored a long period of military rule and moderate cooperation with the USSR, and John Willie Kofi Harlley, who advocated in favor of a quick transfer of power to civilian authorities and full termination of cooperation with the USSR and other socialist countries. According to Ivashutin, opposition to the NLC could come from three main sources: Kofi Abrefa Busia, Nkrumah's former chief political rival, who could unite with Harlley's faction and topple General Ankrah; a group of military officers, led by Brigadier Amenu, who were ready for another coup; and supporters of Kwame Nkrumah. Ivashutin concluded that while there was an increasing number of nationalistically-minded intelligentsia, and government employees had started to speak out in favor of Nkrumah, there was still no developed political organization in Ghana capable of organizing mass rallies in support of the former President. ${ }^{43}$

The Soviet intelligence services were not the only actors working against Western interests in Ghana. Czechoslovakia rivalled Soviet involvement in Ghana, especially in the security sphere. The Czechoslovak intelligence and the KGB had cooperated with each other on security matters since 1960, when both sides endorsed a formal agreement to share operational details and cooperate on "active measures" against the secret services of Western countries, including in African countries. ${ }^{44}$ When Kwame Nkrumah turned increasingly to the Soviet Union as a result of Western actions in the Congo, Czechoslovakia offered its cash, arms, and expertise to Ghana. In 1961, Czechoslovakia started to sell arms to Accra, extended $£ 10$ million in credits and agreed to finance and build in Ghana a training center for members of national liberation movements across Africa. In 1962, Czechoslovak experts were sent to reorganize Ghanaian counterintelligence and to investigate the Kulungugu incident, when a grenade was thrown at Nkrumah in August 1962. ${ }^{45}$ The coup in Accra spurred Prague into action: in April 1966, Prague sent 200 rifles, 100 pistols, and 20 machine guns, along with ammunition and medical supplies for Nkrumah in Accra. ${ }^{46}$ Prague's interest in the country meant that Czechoslovakia had maintained a rezidentura in Accra throughout the early 1960s, with many contacts that could be activated in support of the Ghanaian revolution after the coup.

One of these contacts was Kofi Batsa, a Ghanaian writer and political activist, code name LUPA. Batsa had been actively involved in the youth movement during the 1950s, but had been expelled from the CPP, allegedly because of their affiliation with the Communist World Federation of Trade Unions. He was readmitted in 1961, and his career progressed

\footnotetext{
${ }^{43}$ Petr Ivashutin to CC CPSU (International Department), 19 April 1967, F. 5, OP. 59, D. 388, pp. 73-80.

${ }^{44}$ Pavel Žázek, "Czechoslovak and Soviet State Security Against the West Before 1968" (paper presented at the Contours of Legitimacy in Central Europe: New Approaches in Graduate Studies conference, European Studies Centre, St. Antony's College, Oxford, 2002). Also, see "Record of proceedings between the Soviet KGB and the Interior Ministry of the Czechoslovak Socialist Republic on the expansion of intelligence cooperation," June 1961, History and Public Policy Program Digital Archive, ABS, online at http://digitalarchive.wilsoncenter.org/document/113217 (accessed 2 September 2016), p. 4.

${ }^{45}$ Muehlenbeck, Czechoslovakia in Africa, pp. 75-76.

${ }^{46}$ Ibid., p. 104.
} 
steadily from then onwards: Nkrumah appointed Batsa editor of the influential Ghanaian weekly The Spark and a member of Nkrumah's Committee on Ideology and Propaganda in 1962. Three years later he became the General Secretary of the Pan-African Union of Journalists. The Czechoslovak rezidentura in Accra established regular contacts with Batsa around 1963 and undertook a number of "publishing operations" which, according to an intelligence report of 1968, "made waves and caused official protests by some of the imperialist countries like the USA and FRG." The rezidentura rejected the possibility of recruiting him as an "agent" because of his "bohemian lifestyle," but continued cooperation because of his "positive attitude towards socialist ideas." 47 The NLC imprisoned Batsa, alongside other high-profile functionaries of Nkrumah's regime, shortly after the coup. In June 1967, he was released and approached the Czechoslovak rezident in Ghana, Karel Hotárek, for financial assistance to organize the struggle against the regime. ${ }^{48}$

The 37-year old Major Karel Hotárek (code-named "Holický") had a rich resume by the time of his posting as rezident in Accra in June 1966. Born into a worker's family in the village of Brezi in the Brno district, Hotárek joined the StB in 1949, as a 21-year-old, following high school and a few years as a sales assistant whilst attending an evening school for party workers. He then worked in various posts with the StB before a one-year stint at the intelligence school in Leningrad, USSR, from 1959-1960. His first foreign assignment began in 1962, when he was dispatched as the rezident to Tehran, Iran, for a two-year assignment. In Iran, Hotárek allegedly managed to develop a few secret contacts, worked effectively with Soviet comrades on an operation codenamed "DUHA" and managed to avoid surveillance. ${ }^{49}$ Upon arrival as chief of the Czechoslovak rezidentura in 1966, under the cover of second secretary of the embassy in Accra, Hotárek became a person of interest for the Ghanaian counter-intelligence. His main aim - to establish a net of clandestine contacts and obtain secret documents and information-was thus impaired due to this surveillance. ${ }^{50}$

Nonetheless, the first meeting between Hotárek and Batsa on 6 September 1967 was productive. The two met at the Nungua farm, a location a few kilometers away from Accra, run by Czechoslovakian experts. When Hotárek arrived at the farm at 3 p.m. (under the pretext of buying eggs), Batsa was waiting with a "reliable" taxi-driver. ${ }^{51}$ During a one-hour conversation, Hotárek questioned Batsa about his interactions with the Ghanaian police whilst in prison. Batsa in turn asked for financial assistance for himself and the wife of his friend Kodwo Addison, a ticket to Prague, and for Hotárek to forward a letter to Kwame

\footnotetext{
${ }^{47}$ There is no direct evidence that Kofi Batsa was ever an official "agent". Most likely, the Czechoslovak Intelligence categorized Batsa as the so-called "trusted person", a category which allowed to forge a relationship on an informal basis. For a detailed explanation of this category, see: Viktor Chebrikov et al., Istoriya Sovetskikh Organov Gosudarstvenny Bezopasnosti: Uchebkik (Moscow, 1977), online at http://www.fas.harvard.edu/ hpcws/documents.htm (accessed 12 September 2016), pp. 558-559

48 "Kofi Batsa," 9 February 1968, Archiv Bezpečnostních Složek (ABS), 45044_020, pp. 92-96.

49 "Vec: Zhodnocení práce s. Hotárka v Zahraničí," Josef Janous (Afro-Asian department, chief) to Josef Houska, 1 October 1964, ABS, Personální Depozirář (P.D.) 4172.

50 "Pracovní Hodnocení z Pobytu v Zahniči," Luděk Rivet to Čestmír Podremný, 19 May 1970, ABS, P.D. 4172, pp. 171-173.

51 “Batsa," Hotárek to Prague, 16 September 1967, ABS, 45044_020, pp. 4-6.
} 
Nkrumah and to journalists in Conakry and Mali. Batsa claimed his goal was to stage a counter-coup in Ghana, and he informed Holický that he had already established contacts with former members of Nkrumah's cabinet while in prison. ${ }^{52} \mathrm{He}$ also handed over a detailed analytical note about the situation in Ghana, in which he outlined the difficulties of the Ghanaian regime, pointing to the increase in state-led repression, the dismal state of the economy and internal divisions within the NLC. He concluded that the situation was highly volatile and that the government's downfall was only a matter of who would provide the leadership — and obtain the necessary funds_-for the overthrow of the NLC. ${ }^{53}$ Hotárek came out of the meeting satisfied with the answers and proposed that Batsa should be used for various secret tasks, in accordance with the general plan of the rezidentura. ${ }^{54}$

Prague supported Batsa's initiative. On 5 October 1967, Josef Janouš wrote to the chief of Czechoslovak intelligence, Josef Houska, with an outline of a plan. Batsa would start, Janouš explained, by establishing an illegal organization consisting of reliable rivals of the NLC, including army officers, government functionaries and the non-corrupt officials who had served under Nkrumah. He would simultaneously follow the situation inside the NLC, and in Ghana in general, while also monitoring the activities of right-wing groups and of the Western countries, especially the USA, Great Britain, and West Germany. Janouš believed that cooperation with Batsa was useful and recommended that the Czechoslovakian rezidentura should fulfil some of his requests, including the provision of financial assistance for information, but warned that the operation was very risky and that it was essential for Hotárek to establish secure communications with Batsa. ${ }^{55}$ Less than two weeks later, a senior StB officer in Prague codenamed DUB passed on the decision to Karel Hotárek in Accra: Batsa would be used for intelligence purposes in line with the plan to establish conditions for a left-wing coup — under the condition of strict secrecy, for failure would embarrass Czechoslovakia. He thus instructed Hotárek give him a one-time cash allowance of 500 cedi (equivalent to \$500) and agreed to pass on his letters, including those to Nkrumah, through a 'trusted source' close to the former president. The Soviets had been fully informed and consulted regarding their recommendations, criticism or requests, continued "DUB," as he finished his instruction to the rezident with a list of eleven questions related to practical aspects of Batsa's activities. ${ }^{56}$ The operation was codenamed ALEX.

Most likely, Moscow and Prague initially envisioned an active role for Nkrumah in these schemes, reflected in conversations between the Czechoslovaks and Amílcar Cabral. The leader of the Partido Africano de Independência da Guiné e do Cabo Verde (PAIGC), a movement engaged in a guerrilla war against the Portuguese control of Guinea-Bissau and Cape Verde and based in Conakry, Cabral had received cash, weapons, and training from Czechoslovakia since 1961 ${ }^{57}$ Cabral's Czechoslovak liaisons in Conakry and Prague had a series of conversations with him about Nkrumah's plans and political ambitions in the

\footnotetext{
52 "Akce BAČA - Návrh," Josef Janous to Josef Houska, 5 October 1967, ABS, 45044_020.

53 "Poznámkz k Současné Situaci (záŕí 1967) v Ghaně,” 5 October 1967, ABS, 45044_020.

${ }^{54}$ Holicky to Prague, 16 September 1967, ABS, 45044_020, pp. 4-6.

${ }^{55}$ Josef Janous to Josef Houska, "Akce BAČA - návrh," 5 October 1967, ABS, 45044_020.

${ }^{56}$ Dub (Prague), 18 October 1967, ABS, 45044_020, pp. 44-48.

${ }^{57}$ Telepneva, "Our Sacred Duty," pp. 81-90.
} 
aftermath of the coup. Cabral was a long-time friend of Nkrumah and one of the few regular guests the latter would receive at his residence in Conakry. Czechoslovak intelligence would therefore try to use Cabral's influence with Nkrumah to convince the former President to focus on organizing a resistance movement in Ghana. ${ }^{58}$ Initially pessimistic about Nkrumah's prospects, Cabral became increasingly skeptical of the ex-President's capacity for decisive action. By early 1968, Cabral argued that the ex-President knew little about the situation in Ghana, that he had become more of a philosopher than a politician, and that his plan to liberate the African continent was not realistic. ${ }^{59}$ The extent of Nkrumah's involvement in plans for a counter-coup is not fully clear, but he must have been at least partially informed, given his regular communication with Cabral and representatives from the socialist countries. ${ }^{60}$

Therefore, it may seem puzzling why Prague-clearly with knowledge and approval of their Soviet colleagues-decided to go ahead with operation ALEX. The GRU for one did not believe that Nkrumah's loyalists had much of a chance for a coup against the NLC in the foreseeable future, even if they did note that the existing situation was unstable and could lead to change in the future. In fact, Ivashutin's evaluation of the situation in Ghana was very similar to the CIA's estimate of July 1967. The report underlined Ghana's continuous economic malaise and instability, potentially leading to a takeover by a new regime less friendly to the US. ${ }^{61}$ Kofi Batsa's evaluation of the situation in Ghana was quite similar, although he claimed that Nkrumah's supporters could unite with disgruntled men in the military to topple the NLC. Czechoslovakian intelligence was therefore not far off the mark as far as the general situation in the country was concerned, but it would take much more time for them to determine whether Batsa could deliver on his promises.

\section{Operation ALEX Unfolds}

Operation ALEX went into full gear in early 1968. In a meeting in Accra on 21 January 1968, Batsa shared with rezident Karel Hotárek some details of the illegal organization, apparently consisting of 33 people serving in various government institutions and the military, and headed by a six-member Political Bureau. He asked the rezident to pass on mercury to make explosives and ammunition for a certain type of rifle. The rezidentura admitted that the transportation of mercury and the making of explosives were dangerous, but promised to help and supply Batsa with the requested detonators, and asked for samples so that they could find and adjust ammunition for the appropriate standard. Hotárek entertained some concerns about a lack of consistency in Batsa's information, but his opinion of Batsa was overwhelmingly positive. He saw Batsa as a suitable candidate to organize a resistance

\footnotetext{
58 Josef Janouš (Fourth department of the StB First Directorate, chief), Prague, 25 November 1966, ABS, 43197/020; and Josef Janouš (Fourth department of the StB First Directorate, chief), Prague, 13 February 1967, "Zpráva o Jednání s Amilcarem Cabralem," ABS, 43197_020.

59 "Zpráva o Jednání s Amilcarem Cabralem," Josef Janouš to Prague, 13 February 1967, ABS, 43197/020; and

"Sekretáŕ - Schůzka s Nkrumahem," Peták (Conakry) to Prague, 26 February 1968, ABS, 43197_020.

${ }^{60}$ Milne, Kwame Nkrumah, pp. 3-20.

61 "Special Memorandum Prepared in the Central Intelligence Agency," Washington, 19 July, 1967, in FRUS, 1964-1968-Africa, Vol. XXIV, Document 268, online at https://history.state.gov/historicaldocuments/frus1964-68v24/d268 (accessed 9 September 2016)
} 
movement in Ghana, while Prague was to follow developments in the country and seek to establish the Czechoslovak role in the operation, scheduled for October $1968 .{ }^{62}$ In February, Czechoslovak intelligence services and their counterparts in the KGB convened in Moscow for consultations. The Soviet intelligence apparently believed the significance of the operation was high, as they pledged cooperation and assistance in the organization and delivery of materials. ${ }^{63}$

However, Czechoslovak intelligence became concerned with Batsa's progress. Over the course of several meetings with Batsa in February 1968, Hotárek grew increasingly skeptical of the planned coup's likelihood of success. He argued that the operation was quite risky and the conspirators' capabilities were minimal, with preparations likely to take a very long time. He was particularly concerned about surveillance and Batsa's carelessness in this respect. ${ }^{64}$ In March, Prague dispatched DUB to Accra to clarify the plan of action. When "DUB," Hotárek and Batsa met at the Nungua farm on 20 March, the former complained about a lack of specific information about the illegal organization and asked Batsa for details about the men involved, the security regimes of key government buildings and group capabilities (leadership, security, military equipment, etc). ${ }^{65}$ In yet another meeting on 2 April, DUB informed Batsa that General Ankrah had ordered a strengthening of security around key government buildings due to security concerns and yet again asked for specific information about the operation, as well as the details of Willy Brandt's visit to Ghana. Batsa complained about surveillance, but promised to deliver on some of the requests. ${ }^{66}$

An intervention from Prague had limited results. Hotárek grew increasingly hostile toward what he described as Batsa's lack of seriousness and preparation. In a series of reports to Prague, he complained that Batsa did not produce a complete note about the situation in Ghana. Moreover, he neither managed to answer any questions about the security arrangements at key locations in Accra nor present any specific operational plans. Hotárek concluded that Batsa was not up to the task of organizing a coup. He claimed that his attitudes were superficial, "typically African," in his words. The plan for the operation was not ready, as he did not even know the security arrangements at key locations, and thus claimed Batsa was not capable of undertaking a coup. ${ }^{67}$

Nonetheless, Czechoslovak intelligence seemed optimistic about the operation. A lengthy report from the end of May stated that the situation in Ghana remained volatile and that the NLC feared a coup attempt and thus had taken weapons away from military garrisons, storing them in the central military warehouse in Accra. This was fortunate because it would allow Nkrumah's supporters to undertake a coup with a small group of armed men. The whole operation thus hinged upon two officers of the Ghanaian army,

\footnotetext{
62 "Kofi Batsa," 9 February 1968, ABS, 45044_020, pp. 91-96.

${ }^{63}$ Petr Zídek and Karel Sieber, Československo a Subsaharská Afrika v Letech 1948-1989 (Prague: Ústav Mezinárodních Vztahů, 2007), pp. 73-74.

64 "Schůzky s Typem LUPOU ve Dnech: 1.2.68, 4.2.68, 18.2.68, 25.2.67," 1 March 1968, ABS, 45044_020, pp. 107-108.

65 "LUPA - záznam o schůzce,” Dub (Accra), 20 March 1968, ABS, 45044_020, pp. 114-115.

66 "LUPA - Záznam o Schůzce,” Dub (Accra), 4 April 1968, ABS, 45044_020, pp. 115-117.

67 "Věc: schůzky typem LUPOU ve dnech 3.5.68, 18.5.68, 28.5.68," 30 May 1968, ABS, 45044_020, pp. 122123.
} 
identified as Asare and Tetteh, who were supposed to lead the insulation of the NLC's leadership with the forces of the Accra garrisons and with help from students at the Teshie Military Academy. However, the report acknowledged that many problems remained. One problem was that Asare had failed to give samples of weaponry with instructions on the quantity of the required ammunition making it impossible to transfer the necessary weapons to the capital. Another problem was that Batsa had not yet prepared a tactical plan for the operation. The report concluded that the Czechoslovak rezidentura in Accra would have to press Batsa for missing information and specific plans for the coup. Czechoslovak intelligence would then analyze the plan and draw up a new one if necessary. ${ }^{68}$ The plan remained active until Kofi Batsa was arrested by the Ghanaian police on 12 August 1968. Batsa writes: "There was a rumour of an attempted coup to restore Nkrumah and I was put back in jail. I was accused of concealing arms and plotting a coup, of being in touch with Kwame Nkrumah, and of running round the country organizing against the military government." 69

Kofi Batsa's arrest did not signal an end to the operation as the Soviet and Czechoslovak intelligence network clearly involved more than one person. One of the people involved was Kwesi Amoako-Atta, a former deputy governor of the Bank of Ghana and Finance Minister under Nkrumah, who had been arrested alongside Batsa in the aftermath of the coup. Upon his release in 1967, Amoako-Atta received \$1,000 from Moscow in the form of "financial compensation for the purged supporters of Nkrumah." "70 Amoako-Atta was also in conversation with Hotárek, to whom he confirmed the existence of an illegal organization preparing a coup, but rejected Batsa's participation because of his "loose tongue." October 1968, Josef Janouš, writing to the newly established chief of intelligence, Miloslav Cada, explained that Batsa's understanding of preparations for the coup were superficial and that he could not fulfil any of Prague's requests about the preparation of a military plan, even though he had established contacts with a number of important people. However, Janouš ruled out the possibility of Batsa being a double agent. Therefore, operation ALEX was not compromised. ${ }^{72}$

The GRU, meanwhile, continued to report about the situation in Ghana. Petr Ivashutin submitted a lengthy report in July; the GRU chief claimed that the opposition lacked an organized force capable of replacing the NLC. ${ }^{73}$ Only on 20 August did he inform the International Department that in June a group of Nkrumah's supporters had established an organization called the "Progressive People's Party" with the aim of winning the upcoming elections and undertaking broad socio-economic change on the basis of scientific socialism. According to GRU data, the party was also preparing to take power by force on 31 August or 7 September 1968. The plotters apparently had several meetings to discuss the plan of a coup,

\footnotetext{
68 "Stav akce ALEX ke konci května 1968," ABS, 45044_020, pp. 11-14.

${ }^{69}$ Kofi Batsa, The Spark: Times Behind Me: from Kwame Nkrumah to Hilla Limann (London: Collins, 1985), pp. 44-45.

70 “The Papers of Vasiliy Mitrokhin," GBR/0014/MITN 2/15, N 545, p. 122.

71 "Agent LUPA s Souvislosti s Akcí ALEX," Josef Janouš to Miloslav Čada, 4 October 1968, ABS, 4544 _020.

72 "LUPA Záznam o Kontaktu,” Holicky, 4 September 1969, ABS, 45044_020, pp. 164-166.

${ }^{73}$ Petr Ivashutin to CC CPSU (International Department), RGANI, F. 5, Op. 60, D. 454, pp.173-183.
} 
drawn up by the head of Nkrumah's military intelligence, General Hassan. Ivashutin concluded that the plotters could indeed go ahead with the plan but cautioned that the participation of so many people in the discussions would compromise the operation. ${ }^{74}$ Apart from a series of events, such as the arrest of Soviet trawlers offshore near Takoradi in October on suspicion of landing mines and the arrest of Air Marshal Michael Otu, the former commander of the Ghanaian armed forces, on suspicions of a coup attempt, Nkrumah's own letter to June Milne from 21 December 1968 hints that he had good reasons to believe a coup attempt was imminent:

As I write, no action has taken place at home. The whole place is rotten to the core and rotten ripe for the 'ballon' [sic]. Why it has not gone up I can't understand. I was made to understand that something was going to happen around this time, and nothing has happened. I am afraid that if they keep postponing and dragging on, things might be difficult. The more confused and pressed the enemy, the more erratic, irresponsible and ruthless it becomes. ${ }^{75}$

The activism of the Czechoslovak rezidentura in Accra slowed down after 1968. Karel Hotárek would continue meetings with a number of contacts over the next few years, but it seemed that the Czechoslovak rezidentura would mostly gather information rather than engage in new operations. ${ }^{76}$ The Czechoslovak rezident would meet with Kofi Batsa again in August 1969, following his release, but this time Hotárek would not conceal his irritation, apparently telling Batsa he was not serious, that he would speak about socialism and progress, but would not do anything to make it happen. ${ }^{77}$ One year later, Czechoslovakian intelligence decided to officially terminate all contacts with Batsa since Prague did not believe he was serious enough whilst also remaining under constant surveillance. The overall cost of the failed operation was 1500 Ghanaian cedi for operation ALEX (equivalent to $\$ 1,500)$ and 800 cedi for Batsa's personal use. ${ }^{78}$

In October 1971, Prague decided to close down its rezidentura in Ghana and transferred their local contacts to their Soviet colleagues. The reasoning behind the decision is not fully clear. One explanation was that the rezidentura found itself in an increasingly difficult situation, as its contacts were constantly under surveillance and were periodically arrested - a potential security threat to both the Czechoslovak and Soviet operations. ${ }^{79}$ Yet another possible explanation was Czechoslovakia's gradual withdrawal from active intelligence operations, except for a few key areas, after a turn inwards in the aftermath of the Prague Spring and Warsaw Pact military intervention in August $1968 .^{80}$

\footnotetext{
${ }^{74}$ Ibid., pp. 184-186.

75 Milne, Kwame Nkrumah, p. 27.

76 "Hodnocení Rozvědného Apravodajství Rezidentury v GHANE zy Období od 1.7.1969 do 31.10.1970," ABS, 81105_013,pp. 51-56.

77 "LUPA Záznam o Kontaktu," Holicky, 4 September 1969, ABS, 45044_020, pp. 164-166.

78 "Rozhodnutí o Uložení Operativního Svaykz," Prague, 12 November 1970, ABS, 45044_000.

79 "Organizační dopis," 18 January 1971, ABS, 81105_014, p. 2; and "Agent LUBA - Návrh Napředání Sovětským Přatelům," 22 August 1971, ABS, 81105_014, pp. 51-52.

80 Žázek, “Czechoslovak and Soviet State Security,” p. 5.
} 
The failure of the coup in Accra and the Prague Spring did not affect Hotárek's career. At the end of his four-year rezidency in May 1970, he returned home with a good record, according to his senior officer, Luděk Rivet. While Hotárek had been initially slow to develop contacts and engage in analytical work, he overcame these deficiencies and showed good results. Over a four-year period, he engaged, developed, and recruited six people in "various categories" who would prove very useful in the task of finding secret documents and information upon Prague's request. In addition, Hotárek stayed committed to the principles of Marxism-Leninism and proletarian internationalism and would cooperate closely with his Soviet colleagues, with whom he would participate in ten "active operations," including a particularly important one against the CIA, according to Rivet. ${ }^{81}$ This short abstract shows that the story of Kofi Batsa and operation ALEX gives us only a small window into the kind of plots that the StB and the KGB were engaged with in post-revolutionary Ghana and their real-and imagined—competition with the Western intelligence services.

The Soviet rezidentura did not give up hope of exerting influence upon the ruling regime through secret intelligence. When General Ignatius Kutu Acheampong took power in yet another coup on 13 January 1972, an officer of the Soviet rezidentura in Accra served as an unofficial security adviser to Acheampong. The KGB's contacts included a number of individuals working for Acheampong's administration in various capacities. ${ }^{82}$ The KGB also recruited several Ghanaians who successfully managed to identify the CIA officers working under the cover of the US Embassy in Accra and install special recording equipment. ${ }^{83}$

\section{CONCLUSION}

The full story of Soviet and Czechoslovakian plans for post-coup Ghana are not yet fully known, but new evidence shows that Moscow did not give up their ambitions in West Africa. While most scholars point to the early 1960s as the key period when the Soviets became disillusioned with the prospects of socialism in Africa, the story of failed attempts to launch a counter-coup in Accra after Nkrumah's fall shows the event was particularly painful for Moscow, perhaps the largest single blow to Soviet policy in the region since the coup that had deposed the first democratically-elected Prime Minister of the Congo, Patrice Lumumba, in 1960. This was due to the clearly pro-Western stance of the new Ghanaian regime and the importance of Kwame Nkrumah, who had been increasingly moving towards the Soviet vision of the world and of American power. One clear indication of this is the decision to dispatch a ship to Conakry upon Nkrumah's request, despite diverging opinions among the members of the CC CPSU Politburo. While that decision was eventually cancelled, the intelligence services in Accra persevered with their plan to launch a left-wing counter-coup with the support of Nkrumah's loyalists and disaffected members of the Ghanaian military. The story therefore shows that the Soviet presence in post-colonial African states was not always a construction of Western propaganda or imagination, even if this influence was fairly limited, as in the post-1966 Ghanaian case.

\footnotetext{
81 "Pracovní Hodnocení z Pobytu v Zahniči," Luděk Rivet to Čestmír Podremný, 19 May 1970, ABS, P.D. 4172, pp. 171-173.

82 “The Papers of Vasiliy Mitrokhin," GBR/0014/MITH 2/15, N544, p. 121 and N750, p. 166.

83 “The Papers of Vasiliy Mitrokhin," GBR/0014/MITH 3/4, p 142.
} 
Operation ALEX attests to this active Soviet involvement. The Czechoslovakian rezidentura in Accra was very receptive in responding to Kofi Batsa's plans to stage a coup, even in the extremely risky conditions existing in post-coup Ghana. Most likely, they originally envisioned Nkrumah playing an active role as leader of an underground resistance movement and prepared his return to Ghana. By 1970, however, they became increasingly skeptical of Nkrumah's potential for a comeback and focused on trying to work from inside the Ghanaian military and security apparatus. The extent of KGB and GRU involvement in the schemes is not fully clear, but the Czechoslovakian documents make it clear that their Soviet colleagues were fully informed and involved, at both the operational and policy level. The Czechoslovakian rezidentura in Conakry was closed in 1971, but the Soviets continued their intelligence work, with some success following Acheampong's coup in 1972.

The story of Soviet and Czechoslovakian involvement in post-Operation ALEX Ghana also highlights the importance of local agency in the story of the Cold War in Africa. While we still do not know the whole story related to the plot, the Soviet and Czechoslovak plans hinged upon Ghanaians such as Kofi Batsa, who was meant to be the driving force behind the coup. His inability to come up with a cohesive military plan and his eventual arrest resulted in little that either the KGB or the $\mathrm{StB}$ was able and willing to do to reverse the situation in Ghana. The Soviet security services—notably the GRU—were also well aware of their limited capabilities to project power at such a great distance and that any kind of support for the coup had to be led by locals.

A major consequence of the Ghanaian coup was therefore the militarization of Soviet relations with the African countries. While the late 1950s and the early 1960s formed a period when the Soviet leadership believed that the key to promoting socialism in Africa lay in encouraging the 'socialist model of development,' Nkrumah's downfall proved to the Soviet leadership yet again that they had mistakenly neglected to engage with the armed and police forces of the newly independent nation-states. In the late 1960s, the Soviet Union would extend its network of relations with the military and intelligence elites of African countries by providing weapons, sending military technicians, and offering military training in the USSR. In addition to traditional allies such as Guinea and Congo-Brazzaville, the Soviet Union would provide substantial military aid to Somalia, Ethiopia, and Nigeria, as the CIA picked up in its report of March 1969. ${ }^{84}$ The same was true of clandestine intelligence operations. If the KGB did not have any active presence in the region until 1961, by 1966, a perpetual war between secret agencies, fueled by internal rivalries, had become the norm, contributing to the polarization of politics in the continent and the demise of African unity as a political project. The Soviet activism in Africa of the 1970s cannot be fully understood without a thorough re-examination of the late 1960s as a decade of often under-the-surface militarization of the Cold War in Sub-Saharan Africa.

\footnotetext{
84 "The Soviets and Black Africa: New Approaches and the African Response," Central Intelligence Agency Report, Office of National Estimates Memorandum, Washington, March 13, 1969, FRUS, 1969-1976, Vol. E-5, Part I, Documents on Sub-Saharan Africa, Document 1, online at https://history.state.gov/historicaldocuments/frus1969-76ve05p1/d1 (accessed 2 September 2016).
} 